Gumeniuk B. N. ${ }^{1}$, Candidate of Medical Sciences, Senior scientist at the Department of Anesthesiology, Intensive Care and Artificial Circulation, https://orcid.org/0000-0002-7954-4769

Dyachenko V. L. ${ }^{1}$, Head of the Blood Transfusion Department

Dyachenko M. V. ${ }^{2}$, Transfusiologist of the highest category

Kalashnikov S. A. ${ }^{1}$, Surgical resident at the Emergency Endovascular Surgery Department, https://orcid.org/00000002-5027-8874

${ }^{1}$ National Amosov Institute of Cardiovascular Surgery of the National Academy of Medical Sciences of Ukraine, Kyiv, Ukraine

${ }^{2}$ Blood Center of the National Military Medical Clinical Center “Main Military Clinical Hospital”, Kyiv, Ukraine

\title{
Prospects for the Use of Donor Blood in a Cardiac Surgery Clinic
}

\begin{abstract}
Investigation of problems of infection among patients with heart disease and blood donors, diagnosis and detection of serological markers of hepatitis B, C, syphilis, HIV infection and alternative development of free donation.

The aim. To analyze the dynamics of serotypes of infections in patients and donors in recent years, and to determine the prospects of free donation in a cardiac surgery clinic.

Materials and methods. The study was performed by means of detection of hepatitis B, hepatitis C, syphilis and HIV infection markers in 19,965 patients with heart diseases and 9,502 donors in 2017-2019, and included analysis of the development of voluntary blood donation in Ukraine.

Results. In 2017-2019, a 4-fold increase in the total amount of donated blood was noted due to the development of Voluntary Blood Donation (VBD) program. In patients with heart diseases requiring surgical treatment, the average rate of infection in this period was 5.76\%. Among blood donors in those years, there was a notable increase in serological markers of syphilis (5.3-fold) and HIV infection (2.3-fold). In the process of examination and procurement of donated blood, the lack of donor blood from relatives of patients is $27 \%$, and the lack of blood from voluntary donors is $17 \%$.

Conclusion. Increase in the amount of donated blood thanks to the first-time donors in the VBD program requires careful laboratory monitoring to detect antibodies to the causative agents of syphilis, hepatitis B, C and HIV, as well as mandatory post-quarantine laboratory monitoring of donor plasma.
\end{abstract}

Keywords: cardiac surgery, donated blood, hepatitis B, hepatitis C, syphilis, HIV.

Introduction. Transfusion of donated blood components remains a hot topic in surgical practice, despite the emergence of new blood saving techniques. In case of a massive blood loss, there is no way of saving the patient without blood transfusion. Donation of blood is being actively supported by the WHO and by government officials in Ukraine. However, blood banking is associated with rejection of significant number of donors due to various infections which can be transmitted by blood transfusion, and due to non-infectious diseases [1, 2, 3, 4]. Some countries have managed to establish effective barriers against infection transmission through blood transfusions. According to the data of the Swedish study, first-time donors do not become active donors without undergoing an evaluation of the risk of carrying infectious agents. In the late 20th century the HIV infection rate in Sweden was 1:1000000, the rate of hepatitis C amounted to 1:100000, and there was no evidence of syphilis infection [5]. Complications of donated blood transfusions can occur in the form of immediate and delayed allergic reactions [6]. Dariusz et al. reported a $0.16 \%$ rate of complications in a series of 58,505 blood transfusions, where the most common were: fever of non-hemolytic origin (36.8\%) and allergic reactions $(30.5 \%)$ mainly after the platelets transfusion [7]. It is worth noting that the incidence of these reactions increased depending on the number of transfusions rather than on the amount of a single transfusion [8]. Other problems of blood donation include the decrease in the number of donors due to the sporadic attitude of the general public towards blood donation as a social project. These problems are substantial for the work of a cardiac surgery clinic. As of today, the attention of the state authorities is focused on the collection of blood components, while the problems of logistics, new diagnostic criteria and safety of 
Table 1

The incidence of detecting serological markers in patients with heart diseases requiring a surgical treatment

\begin{tabular}{lccc} 
Year & $\mathbf{2 0 1 7}$ & $\mathbf{2 0 1 8}$ & $\mathbf{2 0 1 9}$ \\
\hline $\begin{array}{l}\text { Number of } \\
\text { patients }\end{array}$ & 6,232 & 6,658 & 7,073 \\
\hline Anti-HCV & $234(3.7 \%)$ & $216(3.2 \%)$ & $245(3.46 \%)$ \\
\hline HBsAg & $125(2.0 \%)$ & $134(2.01 \%)$ & $110(1.55 \%)$ \\
\hline $\begin{array}{l}\text { Treponemal } \\
\text { antibodies }\end{array}$ & $24(0.38 \%)$ & $14(0.21 \%)$ & $18(0.25 \%)$ \\
\hline HIV antibodies & $10(0.16 \%)$ & $8(0.12 \%)$ & $11(0.16 \%)$ \\
\hline Total & $393(6.3 \%)$ & $372(5.58 \%)$ & $384(5.42 \%)$
\end{tabular}

the collected blood are being overlooked. There is a lack of publications on the cost of the donated blood collection and on the search for new blood-sparing techniques for on-pump cardiac surgical procedures.

Objective. To analyze the dynamics of serotypes of transfusion transmissible infections in patients and donors, to determine problems and perspectives of voluntary blood donation in a cardiac surgery clinic.

Materials and methods. 19,963 patients with congenital and acquired heart diseases and 9,502 donors were tested for serological markers of hepatitis B, hepatitis C, syphilis and HIV infections at the Amosov National Institute of Cardiovascular Surgery of the National Academy of Medical Sciences of Ukraine from 2017 to 2019. In the pre-operative period, all the patients had been diagnosed with heart failure (NYHA class 2 to 4 ) and reduced exercise tolerance. All the patients had been examined before the intervention in accordance with the local protocol: history taking, laboratory testing, electrocardiography, echocardiography, chest X-ray, and heart catheterization. The data was organized and processed using Microsoft Office Excel 2013.

Results and discussion. According to the results of statistical analysis, the incidence of detecting serological
Table 2

Detection of serological markers of infections in donors

\begin{tabular}{lccc} 
Year & $\mathbf{2 0 1 7}$ & $\mathbf{2 0 1 8}$ & $\mathbf{2 0 1 9}$ \\
\hline $\begin{array}{l}\text { Number of } \\
\text { donors }\end{array}$ & 3,160 & 2,958 & 3,384 \\
\hline $\mathrm{HBsAg}$ & $6(0.18 \%)$ & $11(0.37 \%)$ & $8(0.23 \%)$ \\
\hline Anti-HCV & $23(0.72 \%)$ & $39(1.3 \%)$ & $27(0.79 \%)$ \\
\hline $\begin{array}{l}\text { Treponema } \\
\text { antibodies }\end{array}$ & $3(0.09 \%)$ & $6(0.2 \%)$ & $16(0.47 \%)$ \\
\hline HIV antibodies & $3(0.09 \%)$ & $5(0.16 \%)$ & $7(0.21 \%)$ \\
\hline Total & $35(1.1 \%)$ & $61(2.06 \%)$ & $58(1.7 \%)$
\end{tabular}

markers for transfusion transmissible infections in 19,963 patients who underwent at least one surgical procedure between 2017 and 2019 varied from 6.3\% to 5.42\% (Table 1).

Meanwhile (Table 2), there has been a notable rise in these markers in blood donors: from $1.1 \%$ in 2017 to $2.06 \%$ in 2018 and $1.7 \%$ in 2019. The rate of finding antibodies to Treponema pallidum (a pathogen causing syphilis) has risen more than twice in one year: from $0.09 \%$ in 2017 to $0.2 \%$ in 2018 . There was also an upward trend in the detection of HIV antibodies. In 2017, HIV infection was discovered in $0.09 \%$ of the donors, while in 2019 this rate reached $0.21 \%$.

The reasons listed above as well as technical issues contribute to the lack of usable donated blood. According to the data from the Department of blood collection and transfusion, $6 \%$ of the blood collected from active donors was rejected in the period mentioned above (Figure 1).

Among the first-time donors from the Voluntary Blood Donation (VBD) program, the proportion of rejected blood was $17 \%$ (Figure 2).

Among the patients' relatives, the proportion of rejected blood was even higher, i.e. 27\% (Figure 3).

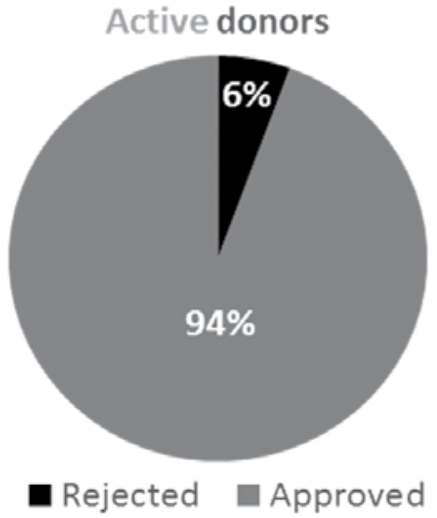

Figure 1. Rejected donated blood from active donors in 2019

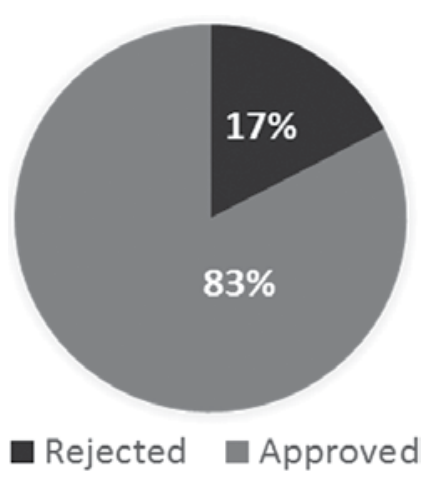

Figure 2. Rejected donated blood from voluntary donors in 2019

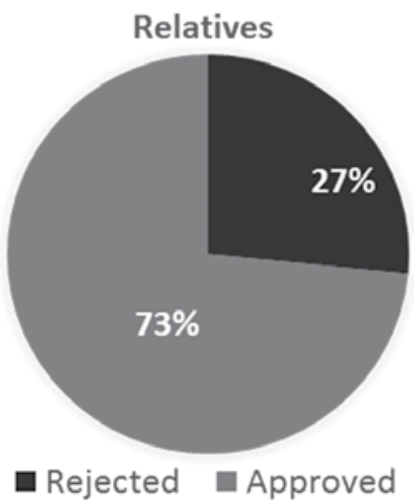

Figure 3. Rejected donated blood from relative donors in 2019 


\section{Table 3}

Fractions of rejected blood in three categories of donors

\begin{tabular}{lcc} 
& Rejected blood & Usable blood \\
\hline Active donors & $6 \%$ & $94 \%$ \\
\hline Relatives & $27 \%$ & $73 \%$ \\
\hline Voluntary donors & $17 \%$ & $83 \%$
\end{tabular}

The percentages for rejected blood are presented in Table 3.

Due to explosive development of diagnostic and surgical techniques, the amount of surgeries lately has been on the rise. Consequently, the demand for donated blood components has risen as well. In recent years, considerable support was obtained from the development of the VBD program which contributed significantly to the amount of blood donations through voluntary donations from the public and employees of large companies. However, the rate of rejected blood has been significantly higher among the sporadic voluntary blood donors (17\%) and among patient's relatives $(27 \%)$ who can be considered as sporadic donors as well. Undoubtedly, the VBD program increased the amount of collected donor blood; however, the incidence of detection of hepatitis C, hepatitis B and HIV serological markers have also increased. These findings suggest a growing need for targeted diagnostics of these and other markers of transfusion transmissible diseases, especially in first-time donors. The growth of the VBD program is shown in Figure 4.

In 2018, donors from the VBD program constituted $27 \%$ of the total amount of donors (Figure 5). The fraction of blood components from the active donors was $43 \%$, and $22 \%$ of blood components for cardiac surgeries were received from the other facilities.

The percentage of donors in 2019 is shown in Figure 6. Due to the increase in the number of voluntary donors, there have been no need for requesting blood components from other facilities.

1203

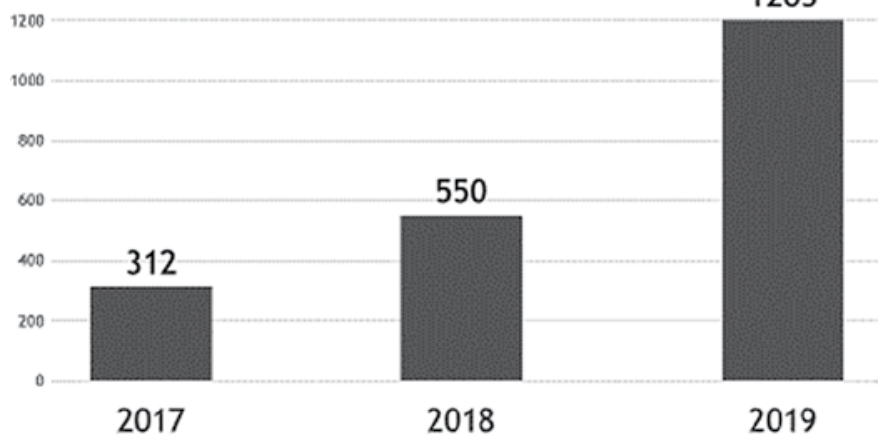

Figure 4. Number of donors in the Voluntary Blood Donation program

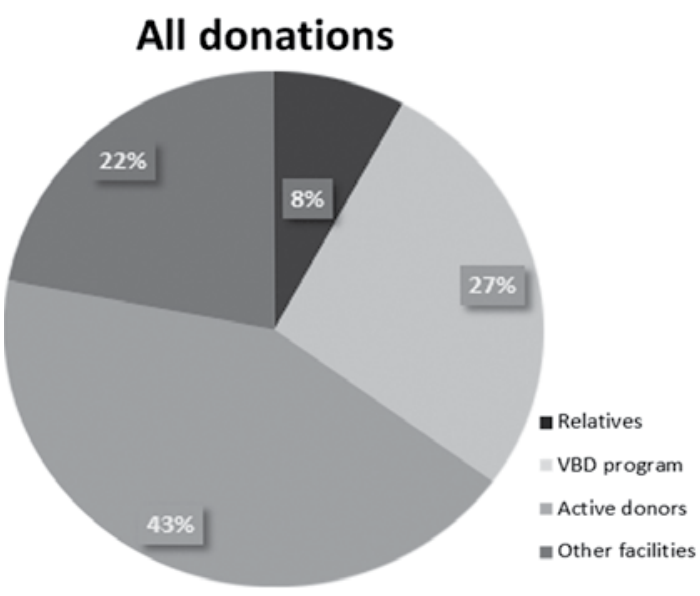

Figure 5. Sources of blood donations in 2018

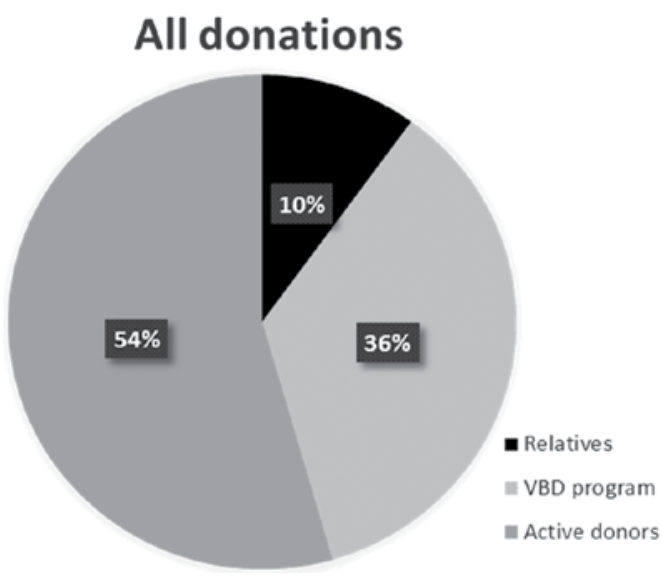

Figure 6. Sources of blood donations in 2019

Implementation of the VBD program was achieved by organizing the off-site events for donor recruitment and blood collection. Compared to 2017, the number of donors in 2019 experienced almost 4-fold growth, which, in turn, have significantly increased the amount of collected blood components in total and per event (Table 4).

The groups of patients who were treated by transfusion of the blood components collected under the VBD program is presented in Table 5.

\section{Table 4}

Results of off-site events of the VBD program

\begin{tabular}{lccc} 
Year & $\mathbf{2 0 1 7}$ & $\mathbf{2 0 1 8}$ & $\mathbf{2 0 1 9}$ \\
\hline Events & 20 & 20 & 47 \\
\hline Donors & 312 & 550 & 1203 \\
\hline $\begin{array}{l}\text { Amount of blood } \\
\text { collected (liters) }\end{array}$ & 113.0 & 221.0 & 535.0
\end{tabular}




\section{Table 5}

The number of patients who were treated by transfusion of the blood components collected under the VBD program

\begin{tabular}{lllllll} 
& $\mathbf{2 0 1 7}$ & $\mathbf{( \% )}$ & $\mathbf{2 0 1 8}$ & $\mathbf{( \% )}$ & $\mathbf{2 0 1 9}$ & $\mathbf{( \% )}$ \\
\hline Children & 165 & $(63.9 \%)$ & 183 & $(53.6 \%)$ & 223 & $(46.6 \%)$ \\
\hline Emergencies & 34 & $(13.1 \%)$ & 43 & $(12.6 \%)$ & 50 & $(10.4 \%)$ \\
\hline $\begin{array}{l}\text { Social } \\
\text { programs }\end{array}$ & 59 & $(22.8 \%)$ & 115 & $(33.7 \%)$ & 205 & $(42.8 \%)$ \\
\hline Total & 258 & $(100 \%)$ & 341 & $(100 \%)$ & 478 & $(100 \%)$
\end{tabular}

This data, as well as the new 2020 Ukrainian legislative acts (№3648 concerning the safety and quality of the donated blood, and №2239 imposing restrictions on the export of the donated blood from the country), encourages optimism for the future of blood donation. These acts should promote the development of blood donation in Ukraine which in turn should increase the hospital's capability of dealing with severe conditions in patients.

The economic cost of preparing the blood components for transfusion is also worth mentioning. The prices of each component are listed in Table 6.

It can be seen that treatment of thrombocytopenia is fairly expensive as 1 unit of the platelet concentrate costs around $\$ 378$. The average volume of blood components used during an on-pump operation about $1,300 \mathrm{ml}$ and translates into an average of $\$ 280$ in costs per patient. The price of preparing the blood components is now almost equal to the price of medications for the treatment of anemia with the blood-sparing technique. For example, a patient with a weight of $74 \mathrm{~kg}$ and hemoglobin at $105 \mathrm{~g} / \mathrm{l}$ should receive $1480 \mathrm{mg}$ of intravenous iron supplementation. The total expenses for drug management of anemia using the blood-sparing technique are presented in Table 7.

Considering that, cardiac operations with the bloodsparing technique which has been developed at the Na-

\section{Table 6}

Prices of preparing various blood components in 2019

\begin{tabular}{lccc} 
Blood component & $\begin{array}{c}\text { Production } \\
\text { per year }\end{array}$ & $\begin{array}{c}\text { Cost of } \\
\text { production } \\
\text { (UAH) }\end{array}$ & $\begin{array}{c}\text { Total cost } \\
\text { (UAH) }\end{array}$ \\
\hline $\begin{array}{l}1 \text { liter of plasma, } \\
\text { machine method }\end{array}$ & 374 & $5,272.0$ & $1,971,728.0$ \\
\hline $\begin{array}{l}1 \text { liter of plasma, } \\
\text { manual method }\end{array}$ & 543 & $6,337.0$ & $3,440,991.0$ \\
\hline $\begin{array}{l}1 \text { liter of red blood } \\
\text { cells, manual method }\end{array}$ & 631 & $4,835.0$ & $3,050,885.0$ \\
\hline $\begin{array}{l}1 \text { unit of platelets } \\
\text { (50 ml) }\end{array}$ & 2,161 & 727.6 & $1,572,343.6$ \\
\hline $\begin{array}{l}\text { 1 unit of platelets } \\
\text { concentrate (300 ml) }\end{array}$ & 158 & $10,776.7$ & $1,702,718.6$ \\
\hline Total & & & $11,738,666.2$
\end{tabular}

\section{Table 7}

Costs of blood-sparing post-operative anemia management

\begin{tabular}{lcc} 
Medication & Number of units & Cost in UAH \\
\hline Erythropoietin i.v. & 30,000 units & $3,513.0$ \\
\hline Iron(III) hydroxide i.v. & $1,480 \mathrm{mg}$ & $3,558.0$ \\
\hline Folic acid p/o & 1 pack & 10.0 \\
\hline Vit. C p/o & 1 pack & 10.0 \\
\hline Vit. B12 i.v. & 1 pack & 30.0 \\
\hline Total & - & 7121.0
\end{tabular}

tional Institute of Cardiovascular Surgery is therefore an economically viable alternative to the blood components transfusion. The technique of saving the autologous blood of the patient during an on-pump operation in different variants can be also considered as an option.

\section{Conclusions}

1. According to our single-center study data, the rate of transfusion transmissible infections in patients with surgical pathology of the heart was $5.42 \%$ and higher in 2017-2019.

2. From 2017 to 2019 there was a 1.6-fold increase in the detection of serological markers of transfusion transmissible infections: there was 5.3-fold increase in the incidence of syphilis and 2.3-fol increase in that of HIV.

3. In 2017-2019, there was a 4-fold increase in blood donation due to the development of the VBD program.

4. In the process of examination and procurement of donated blood, the lack of donor blood from relatives of patients is $27 \%$, and the lack of blood from voluntary donors is $17 \%$.

5. Interventions with the use of donor blood or its components require additional costs compared to operations carried out with the use of blood-saving technologies. This makes the latter a more promising direction for the future development of cardiac surgery.

\section{References}

1. Kitchen AD, Barbara JA. Current Information on the Infectious Risks of Allogeneic Blood Transfusion. Transfusion Alter Transfusion Med. 2008;10(3):102-11. https://doi.org/10.1111/j.1778-428X.2008.00112.x

2. Seighali F, Hosseini Divkolaye NS, Koohi E, Pourfathollah AA, Rahmani AM. The status of blood safety in ECO member states. Blood Transfus. 2015 Oct;13(4):583-7. https://doi.org/10.2450/2015.0035-15

3. Gural AL, Krishtof AL, Shaginian VR. [Optimization of virus protection in blood service]. Laboratory Diagnostics. 2004;3:3-11. Ukrainian.

4. Khubutiya MS, Solonin SA, Bazhenov AI, Kobzeva EN, Smirnova YuV, Godkov MA. [Risks of transmission bloodborne viral infections via blood transfusion, organ and tissue transplantation]. Transplantologiya. The Russian Journal of Transplantation. 2015;(4):23-33.Russian. 
5. Lindholm A. Epidemiology of viral infections in the Swedish blood-donor population. Blood Coagul. Fibrinolysis. 1994 Dec; 5 Suppl 3: S 13-7; discussion S 19. https://doi.org/10.1097/00001721-199412003-00004

6. Frazier SK, Higgins J, Bugajski A, Jones AR, Brown MR. Adverse Reactions to Transfusion of Blood Products and Best Practices for Prevention. Crit Care Nurs Clin North Am. 2017 Sep;29(3):271-290. https://doi.org/10.1016/j. cnc.2017.04.002
7. Timler D, Klepaczka J, Kasielska-Trojan A, Bogusiak K. Analysis of complications after blood components' transfusions. Pol Przegl Chir. 2015 Apr;87(4):166-73. https://doi.org/10.1515/pjs-2015-0039. PMID: 26146115

8. Kato H, Nakayama T, Uruma M, Okuyama Y, Handa M, Tomiyama Y, et al. Repeated exposure rather than the total volume of transfused components may influence the incidence of allergic transfusion reactions. Transfusion. 2015 Nov;55(11):2576-81. https://doi.org/10.1111/trf.13201

\section{Перспективи переливання донорської крові в кардіохірургічній клініці}

Гуменюк Б. Н. ${ }^{1}$, канд. мед. наук, ст. наук. співробітник відділення анестезіології, інтенсивної терапії та штучного кровообігу, https://orcid.org./0000-0002-7954-4769

Дяченко В. Л. ${ }^{1}$, завідувач відділення переливання крові

Дяченко М. В. ${ }^{2}$, лікар-трансфузіолог вищої категорії

Калашников С. А. ${ }^{1}$, хірургічний ординатор відділення екстреної ендоваскулярної хірургіï, https://orcid.org/00000002-5027-8874

${ }^{1}$ ДУ «Національний інститут серцево-судинної хірургії імені М. М. Амосова НАМН України», м. Київ, Україна

${ }^{2}$ Центр крові Національного військово-медичного клінічного центру

«Головний військовий клінічний госпіталь», м Київ, Україна

Резюме. У статті представлено аналіз власного досвіду з виявлення серологічних маркерів гепатиту В, С, сифілісу, ВІЛ-інфекції серед пацієнтів із захворюваннями серця та донорами крові, визначені проблеми розвитку безоплатного донорства та їх альтернативне рішення.

Мета дослідження. Проаналізувати динаміку серотипів інфекцій у пацієнтів і донорів за останні роки та визначити перспективи безоплатного донорства в кардіохірургічній клініці.

Матеріали та методи. Проводили аналіз діагностичного визначення наявності серологічних маркерів гепатиту В, С, сифілісу та ВІЛ-інфекції у відділенні переливання крові серед 19965 хворих із серцево-судинними захворюваннями та серед 9502 донорів з 01.01.2017 по 30.12.2019 рік. Розглянуто проблеми профілактики інфікування компонентів донорської крові у родичів пацієнтів та у первинних донорів за програмою безоплатного донорства, подано економічну оцінку безкровних технологій як альтернативи донорства.

Результати та обговорення. Завдяки розробці програми добровільного донорства у 2017-2019 рр. відбулося збільшення загальної кількості заготовленої крові в 4 рази. У пацієнтів із захворюваннями серця, що потребують хірургічного лікування, середній рівень зараження в цей період становив 5,76 \%. Серед донорів крові в ті роки помітно зросли серологічні маркери сифілісу (у 5,3 раза) та ВІЛ-інфекції (у 2,3 раза). У процесі обстеження та заготівлі донорської крові її нестача у родичів пацієнтів досягала 27 \%, а відсутність вільних донорів - $17 \%$. Економічний підрахунок вартості взяття компонентів донорської крові наближається до вартості препаратів, які використовуються під час корекції анемії за безкровною технологією, що може бути одним з альтернативних шляхів розвитку в кардіохірургії.

Висновок. Збільшення кількості донорської крові за рахунок первинних донорів за програмою безкоштовного донорства вимагає ретельного лабораторного моніторингу для виявлення антитіл до збудника сифілісу, гепатиту В, С і ВІЛ-інфекції та обов'язкового післякарантинного моніторингу донорської плазми. Розвиток програми безоплатного донорства як в економічному, так і в соціальному плані, відкриває також більш широкі можливості для застосування кровозберігаючих технологій у кардіохірургії.

Ключові слова: кардіохірургія, донорська кров, гепатит В, гепатит C, сифіліс, ВІЛ-інфекція.

Стаття надійшла в редакцію 26.10 .2020 р. 